\title{
Comparison of partial malolactic enzyme gene sequences for phylogenetic analysis of some lactic acid bacteria species and relationships with the malic enzyme
}

\author{
Agnès Groisillier and Aline Lonvaud-Funel
}

Faculté d'CEnologie-Unité associe INRA-Université Victor Ségalen-Bordeaux II 351 Cours de la Libération33405 Talence Cédex, France

\begin{abstract}
Author for correspondence: Aline Lonvaud-Funel. Tel: +330556 8464 66. Fax : +3305 56846468 e-mail: aline.lonvaud@oenologie.u-bordeaux2.fr
\end{abstract}

\begin{abstract}
DNA sequences covering $36 \%$ of the mle gene that encodes the malolactic enzyme were determined for 13 strains of lactic acid bacteria, representing Pediococcus, Leuconostoc, Lactobacillus and Oenococcus genera. The sequences were aligned with the corresponding region of $\mathrm{mleS}$ in Lactococcus lactis. The phylogenetic distance matrix tree of all mle sequences was compared with the 165 rRNA phylogenetic tree. The analysis showed that the mle fragment evolved more rapidly than the 165 gene and differently. Pediococcus and Lactobacillus species were intermixed in the 16S rRNA tree whereas they were separated in the mle tree. Leuconostoc mesenteroides and Oenococcus oeni were distinct from other species in the 16S rRNA tree, whereas they were intermixed with Lactobacillus species and Lactococcus lactis in the mle tree. The amino acid sequences deduced from partial mle genes were aligned with 22 malic enzyme sequences and the corresponding phylogenetic tree was constructed. Malic and malolactic enzymes were distinct at the phylogenetic level, except for malic enzymes of yeast and Escherichia coli which were nearer the malolactic enzymes than the other malic enzymes. The analysis of conserved sites showed several interesting amino acids specific to either malic enzyme or malolactic enzyme.
\end{abstract}

Keywords: malolactic enzyme, lactic acid bacteria, phylogeny

\section{INTRODUCTION}

Lactic acid bacteria (LAB) are extensively used in most food and beverage fermentation processes. Their main role is to acidify raw materials by producing large amounts of lactate. The classification of LAB into different genera was formerly based on their morphology, metabolism and physiological characteristics (Buchanan \& Gibbons, 1986; Collins et al., 1987, 1990; Stiles \& Holzapel, 1997; Vandamme et al., 1996). DNA-DNA hybridization (Kawai et al., 1996), 16S rRNA sequencing (Collins et al., 1990, 1993; Lane et al., 1985) and soluble protein patterns (Dicks et al., 1996) have led to the description of new genera. The Leuconostoc group has recently undergone taxonomic changes. 'Leuconostoc paramesenteroides' and related

Abbreviations: $L A B$, lactic acid bacteria; MLE, malolactic enzyme

The GenBank accession number for the 16S rRNA sequence of Lactobacillus salivarius ATCC $11741^{\top}$ is AF089108. species have been reclassified in a new genus Weissella (Collins et al., 1993) on the basis of their 16S rRNA sequences. Phylogenetic studies have also revealed that 'Leuconostoc oenos' is distinct from other Leuconostoc spp. (Martínez-Murcia \& Collins, 1990) and it has been suggested that this organism is an interesting case of a fast-evolving species (Yang \& Woese, 1989). In 1995, the genus Oenococcus was proposed for these bacteria (Dicks et al., 1995). Lactobacillus is the most heterogeneous of the genera included in LAB. Its division into three groups (Buchanan \& Gibbons, 1986 ) is not in agreement with results of phylogenetic analysis (Collins et al., 1991). rRNA sequencing is mostly used for phylogenetic studies of bacteria, but other approaches show it may sometimes not be sufficient for species identification (Fox et al., 1992). Both molecular and classical approaches are necessary for systematic bacterial studies.

In recent years, enzyme-encoding genes have been used for phylogenetic analysis (Birtles \& Raoult, 1996; 
Christensen \& Olsen, 1998; Morse et al., 1996; Roux et al., 1997; Springer et al., 1995). Sequencing of rpoC gene encoding the $\beta^{\prime}$ subunit of DNA-dependent RNA polymerase of the leuconostocs confirms that Oenococcus oeni is distinct from Leuconostoc sensu stricto and Weissella, but these bacteria have not evolved rapidly (Morse et al., 1996). Citrate synthase gene (of Bartonella and Rickettsiae spp.) (Birtles \& Raoult, 1996; Roux et al., 1997) or methyl-coenzyme $\mathrm{M}$ reductase (from the family Methanosarcinaceae) (Springer et al., 1995) are also used as phylogenetic tools because differences between the 16S rRNA sequence are not sufficient to deduce evolutionary relationships. The choice of gene depends on the bacteria studied and also on the taxonomic level. Data on DNA and amino acid sequences are used for the construction of phylogenetic trees.

In most cases of winemaking, after alcoholic fermentation mainly performed by Saccharomyces cerevisiae, some LAB classified as Lactobacillus, Leuconostoc, Pediococcus and especially Oenococcus transform L-malate into L-lactate and carbon dioxide during malolactic fermentation. The nucleic acid sequence of the mle gene, which encodes the malolactic enzyme (MLE), has been determined only for Lactococcus lactis (Ansanay et al., 1993; Denayrolles et al., 1994) and 'Leuconostoc oenos' recently reclassified as $O$. oeni (Labarre et al., 1996). MLE has been purified from several LAB (Caspritz \& Radler, 1983; Lonvaud, 1976; Lonvaud-Funel \& Strasser de Saad, 1982; Naouri et al., 1990; Spettoli et al., 1984). It is composed of two to four identical subunits of $60-70 \mathrm{kDa}$. The protein is strongly homologous to malic enzymes from different organisms, but its activity is similar to malic enzyme plus lactate dehydrogenase in the presence of NAD and $\mathrm{Mn}^{2+}$ without the release of intermediate products. A phylogenetic tree constructed from the sequences of the MLE from Lactococcus lactis and malic enzyme proteins shows that the MLE is most strongly related to the Escherichia coli malic enzyme, and that the bacterial proteins constitute a group distinct from the animal or plant group (Hrdy \& Müller, 1995; Van der Glezen et al., 1997).

We report here the sequencing of a $580 \mathrm{bp}$ fragment of the mle gene from different LAB species: $O$. oeni, Leuconostoc mesenteroides, two Pediococcus spp. and ten strains corresponding to six Lactobacillus spp. These sequences were analysed to build phylogenetic trees which were compared with $16 \mathrm{~S}$ rRNA trees and with physiologic and phenotypic data. The corresponding amino acid sequences were compared with malic enzyme proteins. The analysis shows differences between the two proteins and points to the essential amino acids involved in the enzymic reaction.

\section{METHODS}

Bacterial strains and culture conditions. The sources of the LAB strains used in this study are shown in Table 1. Strains isolated in our laboratory were identified by using the
API 50CH system (API bioMérieux) and DNA-DNA hybridization (Lonvaud-Funel et al., 1991). Cells were grown at $25^{\circ} \mathrm{C}$ in a modified MRS medium: yeast extract, $4 \mathrm{~g} \mathrm{l}^{-1}$; beef extract, $8 \mathrm{~g} \mathrm{l}^{-1}$; bactopeptone, $10 \mathrm{~g} \mathrm{l}^{-1}$; glucose, $10 \mathrm{~g} \mathrm{l}^{-1}$; fructose, $10 \mathrm{~g} \mathrm{l}^{-1}$; DL-malic acid, $10 \mathrm{~g} \mathrm{l}^{-1} ; \mathrm{KH}_{2} \mathrm{PO}_{4}$, $2 \mathrm{gl}^{-1} ; \mathrm{MgSO}_{4} \cdot 7 \mathrm{H}_{2} \mathrm{O}, 0 \cdot 2 \mathrm{gl}^{-1} ; \mathrm{MnSO}_{4} \cdot \mathrm{H}_{2} \mathrm{O}, 0 \cdot 1 \mathrm{~g} \mathrm{l}^{-1}$; Tween $80,1 \mathrm{ml} ; \mathrm{NaOH}, 10 \mathrm{M}$ to adjust $\mathrm{pH}$ to 5 .

Escherichia coli strain XL-1 Blue (Stratagene) (Bullock et al., 1987) was used for amplification of the malic enzyme, for Southern blot and cloning procedures. The culture medium was DYT (Miller, 1972).

Cell-free extract preparation. When $\mathrm{OD}_{600}$ measured in a 932 Uvikon Spectrophotometer (Kontron) reached 0.6, the LAB cells were harvested by centrifugation at $10000 \mathrm{~g}$ for $15 \mathrm{~min}$ at $4{ }^{\circ} \mathrm{C}$. The pellet was suspended in $25 \mathrm{ml}$ phosphate buffer $(0.1 \mathrm{M}, \mathrm{pH} 6)$ or Tris/ $\mathrm{HCl}$ buffer $(0.1 \mathrm{M}, \mathrm{pH} 8)$ and cells were disrupted at $4{ }^{\circ} \mathrm{C}$ with an ultrasonic disintegrator (MSE Scientific Instruments) at $150 \mathrm{~W}$ for $15 \mathrm{~min}$ with alternating sonication and pause every $30 \mathrm{~s}$.

For E. coli, an overnight culture was centrifuged and the pellet was suspended in $4 \mathrm{ml}$ Tris/ $\mathrm{HCl}$ buffer $(0 \cdot 1 \mathrm{M}, \mathrm{pH} 8)$. Cells were disrupted at $4{ }^{\circ} \mathrm{C}$ with an ultrasonic disintegrator (Heat Systems) at $12 \%$ output power for 4 min with alternating sonication and pause every $30 \mathrm{~s}$.

The cell-free extract was separated from the bacterial debris by centrifuging at $14000 \mathrm{~g}$ for $20 \mathrm{~min}$ at $4{ }^{\circ} \mathrm{C}$. The protein concentrations were determined using the BCA Protein Assay (Pierce Interchim) (Smith et al., 1985).

Measurement of enzymic activity. The enzymic activity of MLE was determined by measuring the $\mathrm{CO}_{2}$ released from malic acid with a specific $\mathrm{CO}_{2}$ electrode (Eischweiler and Co., Kiel, Germany), according to the method of Lonvaud \& Ribereau-Gayon (1973). The reaction mixture contained malic acid $(50 \mu \mathrm{mol}), \mathrm{NAD}^{+}(1 \mu \mathrm{mol}), \mathrm{MnCl}_{2}(0 \cdot 2 \mu \mathrm{mol})$ in phosphate buffer $(0 \cdot 1 \mathrm{M}, \mathrm{pH} 6)$. The experiments were conducted at $25^{\circ} \mathrm{C}$ and the reaction was started by adding the cell-free extract. Activity was expressed as $\mu \mathrm{mol} \mathrm{CO}_{2}$ released $\mathrm{min}^{-1}(\mathrm{mg} \text { protein })^{-1}$.

For malic enzyme, the same reaction mixture was used, except for buffer that was either phosphate buffer $(0 \cdot 1 \mathrm{M}$, $\mathrm{pH} 6)$ or Tris/ $\mathrm{HCl}$ buffer $(0.1 \mathrm{M}, \mathrm{pH} 8)$. Activity was measured by the formation of NADH at $340 \mathrm{~nm}$ in a 932 Uvikon Spectrophotometer (Kontron). The activity was expressed as nmol NADH released $\mathrm{min}^{-1}$ (mg protein $)^{-1}$.

Nucleic acid preparation. For LAB, the procedure was derived from that described by Gasson \& Davies (1980). The bacteria were treated with lysozyme $\left(5 \mathrm{mg} \mathrm{ml}^{-1}\right.$ final concn) and the resulting protoplasts were lysed with $20 \%(\mathrm{w} / \mathrm{v})$ SDS. Nucleic acid and cell debris were separated by addition of $\mathrm{NaCl}$ ( $1 \mathrm{M}$ final concn), incubated at $4{ }^{\circ} \mathrm{C}$ and centrifugation. DNA was extracted with phenol/chloroform $(1: 1)$, the upper phase was added with sodium acetate $(3 \mathrm{M}$, pH 5.2) and ethanol. Then, the DNA pellet was suspended in sterile water with RNase $\left(10 \mathrm{mg} \mathrm{ml}^{-1}\right)$.

For $E$. coli, cells were lysed with $3 \%$ SDS, DNA was extracted with phenol/chloroform $(1: 1)$ then treated in the same way as for the LAB. The DNA concentration was estimated after agarose gel electrophoresis by comparing the fluorescence of the bands after staining with ethidium bromide with amounts of standard DNA.

PCR amplifications. To amplify a fragment of the MLE gene of different LAB strains, the primers were chosen in two 
Table 1. Strains used for mle gene sequence phylogenetic studies

ATCC, American Type Collection and Culture; IOEB, Institut d'Eenologie de Bordeaux;

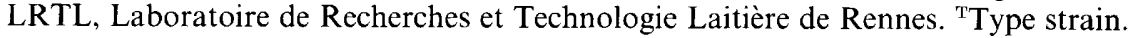

\begin{tabular}{|lll|}
\hline Species & Source/strain no. & Other information \\
\hline Lactococcus lactis & LRTL IL1441 & \\
Oenococcus oeni & ATCC $23279^{\mathrm{T}}$ & \\
Leuconostoc mesenteroides & ATCC $8293^{\mathrm{T}}$ & \\
Pediococcus acidilactici & ATCC 8042 & \\
Pediococcus parvulus & ATCC $19371^{\mathrm{T}}$ & \\
Lactobacillus salivarius & ATCC $11741^{\mathrm{T}}$ & \\
Lactobacillus rhamnosus & ATCC $7469^{\mathrm{T}}$ & \\
Lactobacillus plantarum & ATCC 8014 & \\
Lactobacillus fructivorans & ATCC $8288^{\mathrm{T}}$ & \\
Lactobacillus hilgardii & ATCC $8290^{\mathrm{T}}$ & \\
Lactobacillus hilgardii & IOEB 9101 & Isolated from Muscat \\
Lactobacillus hilgardii & IOEB 9202 & Isolated from Porto \\
Lactobacillus brevis & ATCC $14869^{\mathrm{T}}$ & \\
Lactobacillus brevis & IOEB 9647 & Isolated from sweet white wine \\
\hline
\end{tabular}

conserved amino acid regions of the mles gene of Lactococcus lactis IL 1441 (Ansanay et al., 1993; Denayrolles et al., 1994). These regions were NPVVYDP (amino acids 86-92) and QGTGIV (amino acids 260-265) and the corresponding nucleotides sequences were ATCCAGTTGTTTATGATC (nucleotides 255-276) (sense) and AACAATACCAGTTCCTTG (nucleotides 777-795) (antisense). For amplification of an analogous fragment of NADlinked malic enzyme gene of $E$. coli (Mahayan et al., 1990), the amino acids regions were MPVIYTP (amino acids 109-115) and QGTAAV (amino acids 281-286) and the corresponding nucleotides sequences were TGCCTGTTATTTATACCC (nucleotides 324-345) (sense) and TACCGCCGCAGTGCCCTG (nucleotides 840-858) (antisense).

Approximately $100 \mathrm{ng}$ of genomic DNA was amplified with $2.5 \mathrm{U} \mathrm{Taq}$ polymerase (Stratagene) in a $50 \mu \mathrm{l}$ reaction by using a MiniCycler (MJ Research). Conditions were 30 cycles of $95^{\circ} \mathrm{C}(30 \mathrm{~s}), 38,40$ or $43^{\circ} \mathrm{C}(30 \mathrm{~s})$ according to the strain, and $72{ }^{\circ} \mathrm{C}(2 \mathrm{~min})$. The amplification products were either extracted once with a phenol/chloroform mixture $(1: 1)$, precipitated with sodium acetate $(3 \mathrm{M}, \mathrm{pH} 5 \cdot 2)$ and ethanol, then treated with Klenow enzyme (Boehringer Mannheim) for cloning, or purified on QIAquick spin Columns (Qiagen) for direct sequencing.

Cloning. Purified PCR products were added to a ligation mixture containing EcoRV-cut pBluescriptII KS (Stratagene) and T4-Ligase (Biolabs) as recommended by the manufacturer. This solution was incubated at $16^{\circ} \mathrm{C}$ overnight. Two microlitres were added to $40 \mu \mathrm{l}$ competent cells (XL-1 Blue) and the preparation was electroporated in a Pulser Controller (Bio-Rad). After blue-white selection, plasmids containing DNA fragments were extracted by an alkaline-lysis method (Birnboim \& Doly, 1979) and the inserted fragment length was verified by agarose gel electrophoresis.

Probe labelling and Southern blot hybridization. PCR fragments corresponding to the MLE gene of Lactococcus lactis and malic enzyme gene of $E$. coli were used as probes for Southern blot hybridization. Five hundred nanograms of DNA were labelled with digoxigenin-11-DUTP using the DIG DNA Labelling and Detection Kit (Boehringer Mannheim). For Southern blot, $1 \mu \mathrm{g}$ genomic DNA isolated from each strain was digested with EcoRI or HindIII [4 U $\left.(\mu \mathrm{g} \mathrm{DNA})^{-1}\right]$ and fragments were separated by $1 \%$ agarose gel electrophoresis overnight at $35 \mathrm{~V}$. Digested DNA was denatured then transferred to a nylon membrane using a rapid transfer method (Vacuum Blot; Bio-Rad). Prehybridization $\left(1 \mathrm{~h}\right.$ at $55^{\circ} \mathrm{C}$ ) and hybridization (overnight at $55^{\circ} \mathrm{C}$ ) were performed in a solution containing $5 \times \mathrm{SSC}, 1 \%$ blocking reagent (Boehringer Mannheim), 0.02\% SDS and $0 \cdot 1 \%$ lauroyl sarcosine. For hybridization, $10 \mathrm{ng} \mathrm{ml}^{-1}$ of labelled and denatured probe were added. After incubation, membranes were washed twice at room temperature for $5 \mathrm{~min}$ with $2 \times \mathrm{SSC}$ and twice at $55^{\circ} \mathrm{C}$ for $15 \mathrm{~min}$ in $2 \times \mathrm{SSC}$, $0 \cdot 1 \%$ SDS. The detection was carried out by chemiluminescence using the DIG DNA Labelling and Detection Kit as recommended by the manufacturer.

Sequencing. Purified PCR products or positive inserts were sequenced by using the reagents of a Thermo Sequenase radiolabelled terminator cycle sequencing kit (Amersham Life Science). The primers described for PCR amplifications were used for sequencing. The sequencing reactions were performed by using a MiniCycler with DNA concentration as recommended by the kit. All samples were separated by electrophoresis in $6 \%$ acrylamide gels. For each plasmid or PCR product, the two sense and antisense primers were used and the migration lasted 2 or $6 \mathrm{~h}$. All these conditions made it possible to sequence a $580 \mathrm{bp}$ fragment in double strand.

Analysis of sequence data and construction of phylogenetic trees. Nucleotide sequences of mle genes obtained in this study were compared with mleS of Lactococcus lactis (Ansanay et al., 1993; Denayrolles et al., 1994) and mle $A$ of O. oeni (Labarre et al., 1996). Sequences of 16S rRNA genes, nucleotide sequences of mle genes and partial amino acid sequences of malic and malolactic enzymes were aligned with the CLUSTAL w program (Thompson et al., 1994). For phylogenetic tree construction, gaps (insertion-deletion) 


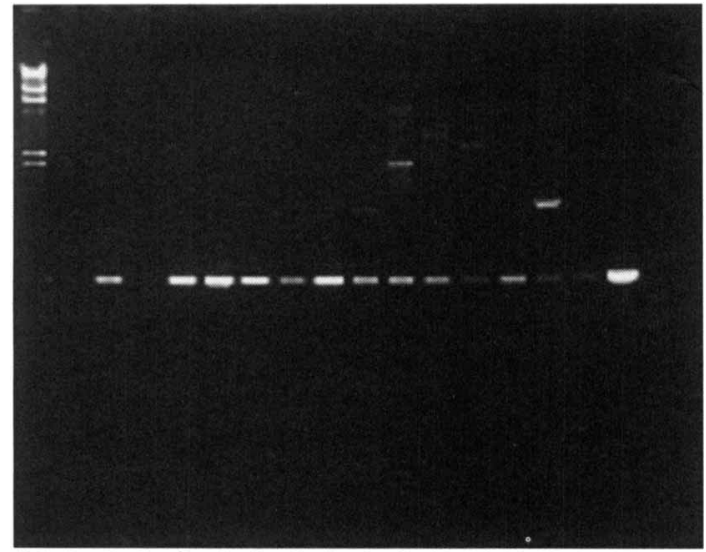

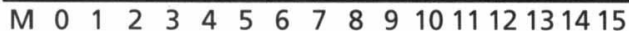

Fig. 1. Amplification profile of $580 \mathrm{bp}$ mle fragment from 14 $L A B$ and one strain of $E$. coli. Lanes: $M$, molecular mass marker d/HindIII $(23130,9416,6557,4361,2322,2027,564,125$ bp); 0 , negative control; 1, Lactococcus lactis LRTL IL1441; 2, E. coli; 3 , Lactobacillus hilgardii ATCC $8290^{\top}$; 4, Lactobacillus hilgardii IOEB 9101; 5, Lactobacillus hilgardii IOEB 9202; 6, 0. oeni ATCC $23279^{\top}$; 7, Leuconostoc mesenteroides ATCC $8293^{\top} ; 8, P$. acidilactici ATCC 8042; 9, $P$. parvulus ATCC 19371 ${ }^{\top} ; 10$, Lactobacillus salivarius ATCC $11741^{\top}$; 11, Lactobacillus rhamnosus ATCC $7469^{\top}$; 12, Lactobacillus plantarum ATCC 8014; 13, Lactobacillus fructivorans ATCC $8288^{\top}$; 14 , Lactobacillus brevis ATCC $14869^{\top}$; 15, Lactobacillus brevis ÁTCC 9647.

were removed from alignments. Distance matrices for DNA and amino acid alignments were calculated by using DNADIST and PROTDIST programs in the PHYLIP software package (Felsenstein, 1989). Trees were inferred from the matrices by using the FITCH program in PHYLIP and then combined to yield a consensus tree (CONSENSE in PHYLIP). The data were also examined by using parsimony analysis (DNAPARS and PROTPARS in PHYLIP). The consensus tree was obtained by CONSENSE in PHYLIP. Bootstrap values were calculated from 100 replicates.

Nucleotide sequence accession numbers. The GenBank accession numbers of the malic enzyme nucleotide sequences, the mle $A$ nucleotide sequence of $O$. oeni and the mleS nucleotide sequence of Lactococcus lactis are shown in Table 3. The mle sequences of the LAB studied have the following GenBank database accession numbers: Lactobacillus salivarius, AF098461; Lactobacillus rhamnosus, AF098777; Lactobacillus brevis, AF098778; Lactobacillus fructivorans, AF098779; O. oeni, AF098780; Lactobacillus hilgardii, AF098781; Leuconostoc mesenteroides, AF098782; Lactobacillus plantarum, AF098783; Pediococcus parvulus, AF098784; Pediococcus acidilactici, AF098785.

\section{RESULTS}

\section{PCR amplification of $580 \mathrm{bp}$ mle gene fragments and sequence determination}

All LAB, except Lactobacillus casei, Enterococcus faecalis and more recently Streptococcus bovis are known to contain malolactic instead of malic activity (Batterman \& Radler, 1990; Kawai et al., 1996; London \& Meyer, 1969). Before the present phylogenetic study, we confirmed that the strains studied had the MLE and not the malic enzyme, also no inactive malic gene. The malolactic activity was measured with a specific $\mathrm{CO}_{2}$ electrode (see Methods). For all strains, the malolactic activity of cell-free extract was of the same order, between 0.2 and $0.5 \mu \mathrm{mol} \mathrm{CO}$ $\min ^{-1} \mathrm{mg}^{-1}$. As expected, these bacteria had no malic enzyme, unlike $E$. coli which was tested as a control.

The mleS gene from Lactococcus lactis was used to

Table 2. Percentage similarity between mle sequences and between $16 \mathrm{~S}$ rRNA gene sequences

The values on the upper right are levels of mle sequence similarity, and the values on the lower left are levels of $16 \mathrm{~S}$ rRNA sequence similarity.

\begin{tabular}{|c|c|c|c|c|c|c|c|c|c|c|c|c|}
\hline Strain & 1 & 2 & 3 & 4 & 5 & 6 & 7 & 8 & 9 & 10 & 11 & 12 \\
\hline 1 Escherichia coli* & & 33 & 32 & 33 & 34 & 34 & 28 & 31 & 33 & 31 & 31 & 38 \\
\hline 2 Lactococcus lactis & 75 & & 67 & 72 & 72 & 69 & 38 & 36 & 69 & 66 & 70 & 73 \\
\hline 3 Leuconostoc mesenteroides & 77 & 81 & & 69 & 68 & 67 & 42 & 38 & 72 & 72 & 64 & 67 \\
\hline 4 Oenococcus oeni & 73 & 80 & 84 & & 67 & 67 & 38 & 38 & 64 & 65 & 64 & 69 \\
\hline 5 Pediococcus parvulus & 77 & 85 & 85 & 82 & & 78 & 36 & 36 & 66 & 68 & 68 & 75 \\
\hline 6 Pediococcus acidilactici & 77 & 84 & 85 & 81 & 96 & & 38 & 40 & 67 & 68 & 70 & 73 \\
\hline 7 Lactobacillus salivarius & 78 & 84 & 85 & 82 & 92 & 92 & & 75 & 39 & 41 & 41 & 40 \\
\hline 8 Lactobacillus rhamnosus & 78 & 84 & 85 & 82 & 94 & 93 & 93 & & 37 & 38 & 39 & 39 \\
\hline 9 Lactobacillus brevis & 73 & 82 & 82 & 79 & 90 & 90 & 87 & 88 & & 77 & 63 & 66 \\
\hline 10 Lactobacillus plantarum & 77 & 84 & 85 & 82 & 93 & 93 & 91 & 92 & 90 & & 66 & 69 \\
\hline 11 Lactobacillus fructivorans & 77 & 84 & 84 & 82 & 94 & 94 & 92 & 93 & 89 & 92 & & 71 \\
\hline 12 Lactobacillus hilgardii & 76 & 84 & 84 & 82 & 94 & 93 & 92 & 93 & 90 & 92 & 93 & \\
\hline
\end{tabular}

* Malic enzyme gene sequence. 

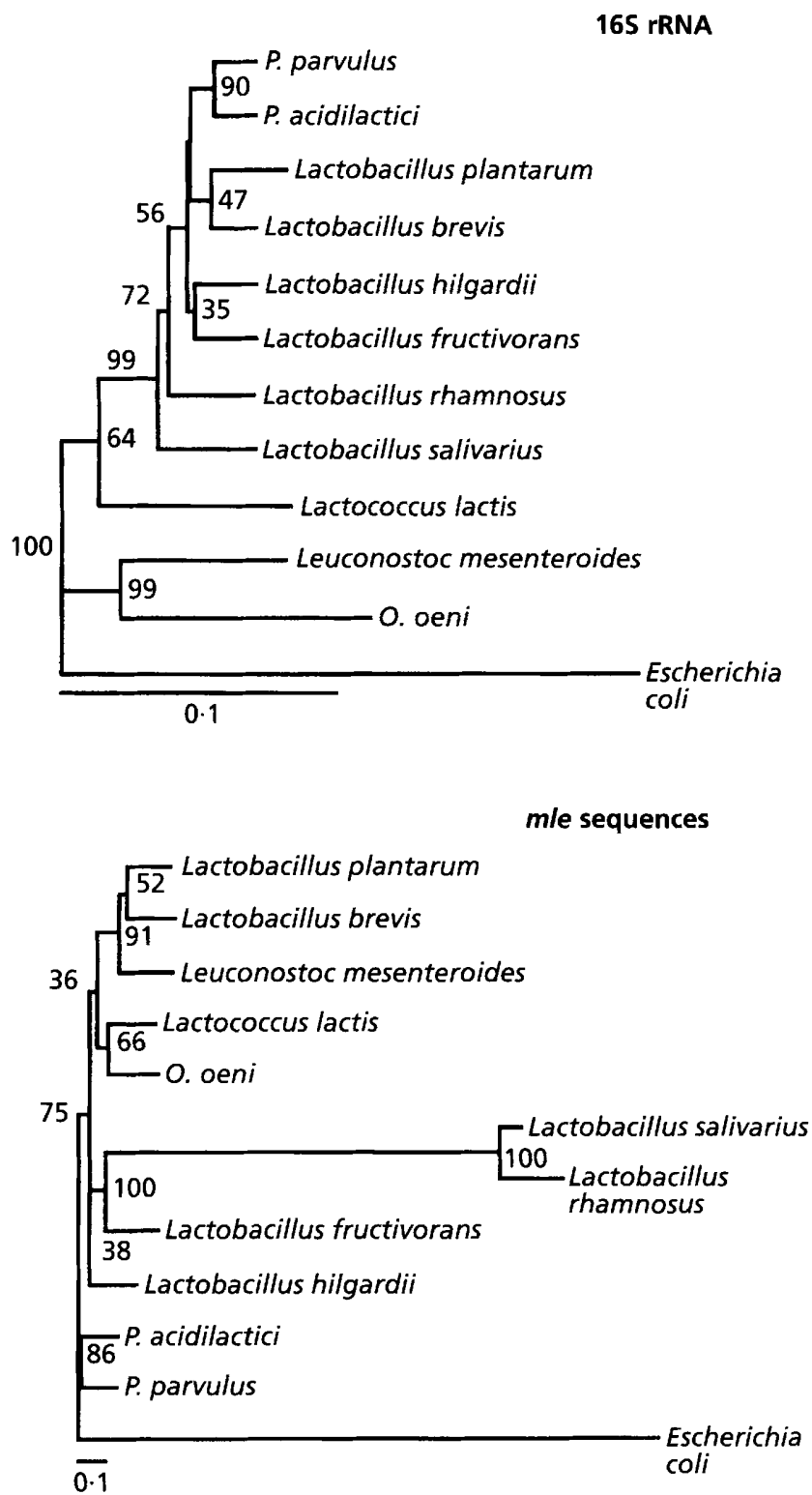

Fig. 2. Comparison of $16 \mathrm{~S}$ rRNA and mle Fitch distance matrix trees. The numbers are parsimony bootstrap values. The scale bar indicates 10 estimated changes per 100 positions.

choose two primers for PCR amplification of an approximately $580 \mathrm{bp}$ region of the mle gene from thirteen LAB strains. In Lactococcus lactis, this region consisted of $36 \%$ of mleS gene which contains the malate-binding site (Viljoen et al., 1994), the ADPbinding $\beta \alpha \beta$ fold region (Wierenga et al., 1985) and a region described as the malic enzyme signature in protein databases (Bairoch, 1991). Moreover, two corresponding primers were chosen from the $E$. coli malic enzyme gene. These two pairs of oligonucleotides were tested on the thirteen strains of bacteria, on Lactococcus lactis and on E. coli. Results of amplification with mle primers are shown in Fig. 1. For all the strains, an approximately $580 \mathrm{bp}$ fragment was obtained, except for E. coli. In the same conditions, no fragment was obtained with malic enzyme primers, except for $E$. coli (data not shown). The $580 \mathrm{bp}$ fragment of mleS in Lactococcus lactis and the $580 \mathrm{bp}$ fragment of malic enzyme in $E$. coli were used as probes in Southern blot hybridization. Genomic DNA of bacteria were successively digested with EcoRI and HindIII. The malic enzyme probe did not hybridize with DNA of LAB, whereas only one signal was obtained for each lactic acid bacterium, with the mle probe (data not shown).

The purified PCR fragments were cloned in pBluescriptII KS and sequenced. Nucleotide sequences obtained for all strains were aligned with the mleS gene, which confirmed that part of the malolactic genes really had been amplified. For three strains isolated in our laboratory, Lactobacillus hilgardii IOEB 9101, Lactobacillus hilgardii IOEB 9202 and Lactobacillus brevis IOEB 9647, the same sequence was obtained. This sequence was identical to the mle of Lactobacillus hilgardii ATCC $8290^{\mathrm{T}}$. The sequence obtained for $O$. oeni ATCC $23279^{\mathrm{T}}$ was compared to the MLE (mleA) of Leuconostoc oenos IOEB 8413 (named Lo84.13 by Labarre et al., 1996). Results show that these two sequences are exactly the same.

\section{Comparisons and phylogenetic analysis}

A pairwise comparison of mle sequences revealed similarity values between 36 and $78 \%$ for LAB (Table 2). There were two distinct groups: first, Lactobacillus salivarius and Lactobacillus rhamnosus which are only $36-42 \%$ similar to other mle sequences; and a second group composed of Lactococcus lactis, Leuconostoc mesenteroides, O. oeni, P. parvulus, $P$. acidilactici, Lactobacillus brevis, Lactobacillus plantarum, Lactobacillus fructivorans and Lactobacillus hilgardii (63$78 \%$ ). The percentage of similarity between mle sequences and the malic enzyme sequence of $E$. coli was lower (28-34\%), except for Lactobacillus hilgardii $(38 \%)$. Table 2 shows a pairwise comparison of $16 \mathrm{~S}$ rRNA sequences of the same strains. The similarity values were $79-96 \%$ for LAB and were between $73-78 \%$ when these Gram-positive bacteria were compared with $E$. coli.

Before phylogenetic tree construction and in order to minimize alignment ambiguities, all deletion and insertion differences between sequences were removed. The $\mathrm{G}+\mathrm{C}$ percentages of these eleven species, ranging from 34 to $47 \mathrm{~mol} \%$ (De Roissart \& Luquet, 1994), do not influence tree analysis. Dendrograms were inferred by using matrix distance and parsimony methods. The analysis of the mle and 16S rRNA sequence data by these two methods yielded slightly different trees. Fig. 2 shows the trees obtained with the Fitch method and the parsimony bootstrap values for 100 replicates. $E$. coli was used as the outgroup. The 16S rRNA sequences tree showed three distinct groups of LAB: Lactococcus lactis alone, Leuconostoc mesenteroides 
Table 3. Malic and malolactic sequences included in this study

\begin{tabular}{|c|c|c|c|}
\hline Species & $\begin{array}{l}\text { Subcellular } \\
\text { location }\end{array}$ & Accession no. & Reference \\
\hline Amaranthus hypochondriacus & Mitochondrion & U01162 & Long et al. (1994) \\
\hline Anas platyrhynchos & Cytosol & $\mathrm{X} 66418$ & Hsu et al. (1992) \\
\hline Ascaris suum & Mitochondrion & M81055 & Kulkarni et al. (1993) \\
\hline Colombia livia & Cytosol & L09233 & Chou et al. (1994) \\
\hline Escherichia coli & & $\mathrm{P} 26616$ & Mahayan et al. (1990) \\
\hline Flavernia trinervia & Chloroplast & $\mathrm{X} 57142$ & Borshc \& Weathoff (1990) \\
\hline Giardia intestinalis & $?$ & U59300 & Sanchez et al. (1996) \\
\hline Homo sapiens & Cytosol & L34035 & Gonzalez-Manchon et al. (1995) \\
\hline Homo sapiens & Mitochondrion & M55905 & Loeber et al. (1991) \\
\hline Lactococcus lactis & mles & X71897 & $\begin{array}{l}\text { Ansanay et al. (1993), Denayrolles et al. } \\
\text { (1994) }\end{array}$ \\
\hline Mesenbryanthenum crystallinum & Cytosol & X64434 & Cushman (1992) \\
\hline Mus musculus & Cytosol & M26756 & Bagchi et al. (1986) \\
\hline Neocallimastix frontalis & Hydrogenosome & U62041 & Van der Glezen et al. (1997) \\
\hline Oenococcus oeni & mleA & X82326 & Labarre et al. (1996) \\
\hline Oryza sativa & Chloroplast & D16499 & Fushimi et al. (1994) \\
\hline Phaesolus vulgaris & $?$ & J03825 & Walter et al. (1990) \\
\hline Populus trichocarpa & Cytosol & $\mathrm{X} 56233$ & Van Doorsselaered et al. (1991) \\
\hline Saccharomyces cerevisiae & Mitochondrion & Z28029 & Boles et al. (1998) \\
\hline Schizosaccharomyces pombe & $?$ & U00621 & Viljoen et al. (1994) \\
\hline Solanum tuberosum & Mitochondrion & Z23023 & Winning et al. (1994) \\
\hline Sus scrofa & Cytosol & X93016 & Unpublished \\
\hline Trichomonas vaginalis & Hydrogenosome & U16836 & Hrdy \& Müller (1995) \\
\hline Vitis vinifera & Cytosol & L34836 & Franke et al. (1995) \\
\hline Zea mays & Chloroplast & $\mathrm{J} 05130$ & Rothermel \& Nelson (1989) \\
\hline
\end{tabular}

and $O$. oeni, then all the other species. In the mle sequence phylogenetic tree, the genus Pediococcus was separated from the other LAB. Lactococcus lactis, Leuconostoc mesenteroides and O.oeni were intermixed with the Lactobacillus spp.

A phylogenetic tree was constructed with amino acid sequences of mle fragments of LAB and malic fragments of species listed in Table 3 (Fig. 3). The analysis confirmed results obtained in previous studies (Hrdy \& Müller, 1995; Van der Glezen et al., 1997). Malic and malolactic enzymes were clearly separated. In addition, this tree shows that malic enzymes of yeast (Saccharomyces cerevisiae and Schizosaccharomyces pombe) and $E$. coli are nearer the MLEs than other malic enzymes.

\section{Comparison of amino acid sequences between mle fragments and malic enzymes}

The amino acid sequences of mle protein deduced from the ORF were compared with 22 related malic enzyme sequences available in databases (Table 3). This region had approximately the same size in all malic enzymes whereas the size of total proteins was not the same. The alignment shown in Fig. 4 demonstrates the similarity of MLEs with all these enzymes and shows identical and similar amino acids not only for malic and malolactic enzymes but also for each enzyme. Although a crystallographic three-dimensional structure is not yet available for any malic or malolactic enzymes, four functionally important domains have been identified (Bairoch, 1991; Viljoen et al., 1994; Wierenga et al., 1985). Three of these four regions were analysed in the present study and the corresponding consensus regions are presented in Fig. 5. The box III sequence is exactly the consensus between all malic and malolactic enzymes. Asp ${ }^{258}$ (second $D$ in FNDDIQGT sequence) in pigeon liver malic enzyme is the metal coordinate (Wei et al., 1994). Four mutant enzymes substituted at $\mathrm{Asp}^{258}$ with glutamate, asparagine, lysine or alanine were inactive. Taken together with these results, the fact that this aspartate is conserved in all malic enzymes and seven MLEs suggests that it is essential for metal binding and thus catalytic activity. Malate-binding site and box I were also highly conserved, but Fig. 5 shows some interesting differences. The cysteine in the malatebinding site, which is essential for the activity of several malic enzymes (Chang et al., 1993; Gavva et al., 1991), was replaced by isoleucine in yeast malic enzymes and all MLEs. Moreover, arginine in box I was replaced by glycine in yeast malic enzymes and malolactic enzymes. 


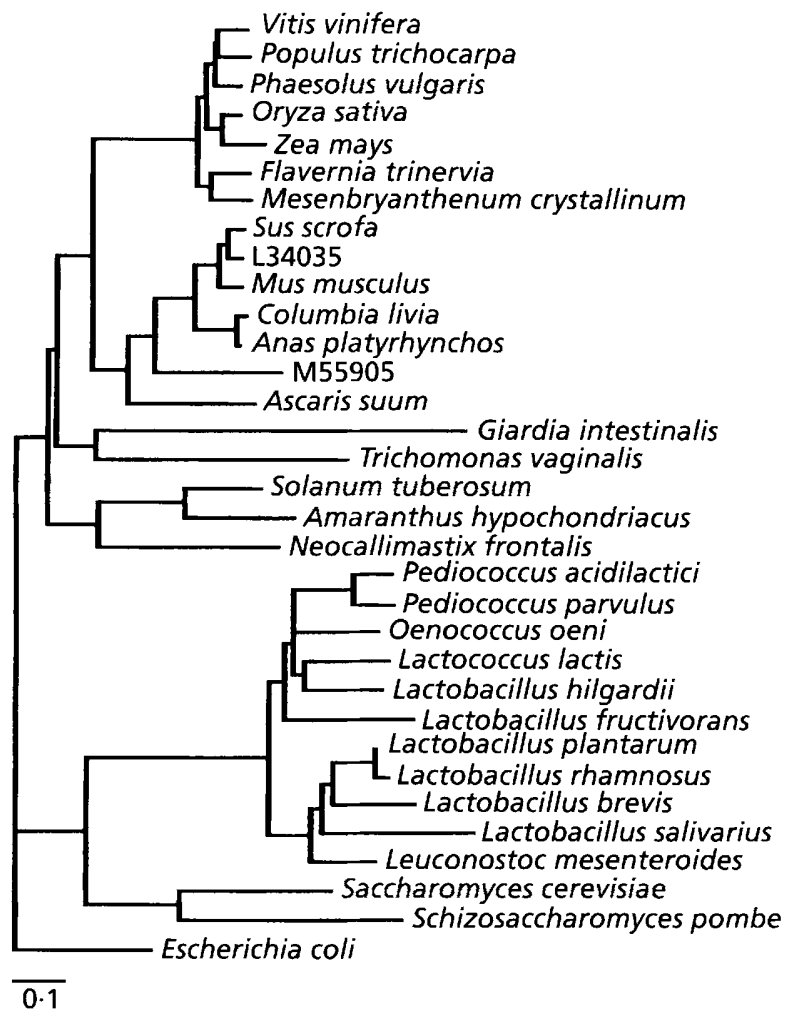

Fig. 3. Fitch distance matrix tree of amino acid sequences of mle and malic enzymes. The scale bar indicates 10 estimated changes per 10 positions.

\section{DISCUSSION}

This study shows that of the LAB we tested and which have no malic enzyme activity, none has any malic enzyme gene either mutated or disrupted. Amplification and sequencing of 13 mle fragments showed that this malolactic enzyme is highly conserved in LAB. The reliability of the sequence data generated from PCR analysis was examined. Products obtained from independent PCR for the mleS fragment and $E$. coli malic enzyme fragment were sequenced. Although Taq polymerase was used, sequencing results did not show any errors. Among the bacteria studied, three strains were from IOEB: Lactobacillus hilgardii 9101 and 9202 and Lactobacillus brevis 9647. Their malolactic sequences were identical to the mle fragment of Lactobacillus hilgardii ATCC $8290^{\mathrm{T}}$. The result for Lactobacillus brevis IOEB 9647 confirmed other current studies in our laboratory. Genomic DNA from strains which cross-hybridize with Lactobacillus brevis and Lactobacillus hilgardii were previously classified as Lactobacillus brevis due partly to their ability to ferment arabinose, unlike Lactobacillus hilgardii. However, fingerprinting and partial 16S rRNA sequencing has made it possible to classify arabinosefermenting strains as Lactobacillus hilgardii spp. (Sohier et al., 1999). In addition, for four strains of the same species Lactobacillus hilgardii, we obtained four identical nucleotidic sequences, which suggests the conservation of mle within this species. The partial sequence of $O$. oeni ATCC $23279^{\mathrm{T}}$ mle was also exactly identical to the mle $A$ of $O$. oeni IOEB 8413 (Labarre $e t$ al., 1996). In a recent paper, mle-targeted primers were used for rapid identification and detection of $O$. oen $i$ in wine (Zapparoli et al., 1998). Therefore, this enzyme appears to have an identical sequence at the species level. From this, $O$. oeni seems to be a homogeneous species (Zavaleta et al., 1997). It would be interesting to know if MLE is homogeneous or heterogeneous in species containing subspecies such as Leuconostoc mesenteroides or Lactococcus lactis.

\section{S rRNA phylogenetic analysis}

Usually, an unknown strain is first identified and classified by conventional morphological, physiological and biochemical methods. In addition, molecular methods are now available. For example, close relationships (at species and subspecies level) can be determined with DNA-DNA homology studies (Johnson, 1984). Yet some species, such as Lactobacillus hilgardii and Lactobacillus brevis, can crosshybridize and conventional techniques are not sufficient. Comparison of $16 \mathrm{~S}$ rRNA sequences is currently the most powerful and accurate technique for determining phylogenetic relationships between micro-organisms (Woese, 1987). In addition, rRNA sequencing is a suitable tool for classification of $\mathrm{LAB}$, as exemplified by the descriptions of new genera (Collins et al., 1990, 1993; Wallbanks et al., 1990). The LAB have been classified at the genus level in four groups (Salminen \& Von Wright, 1998). In 1991, Collins et al. studied 16S rRNA sequences of 55 species of Lactobacillus genera and several bordering species (Collins et al., 1991). Results show that the genus Lactobacillus is separated into three groups; Lactobacillus delbrueckii, Lactobacillus casei-Pediococcus and Leuconostoc paramesenteroides. According to these authors, the strains of Lactobacillus and Pediococcus in our study are included in the second group. These species really form a supercluster within LAB (Fig. 2). Therefore, there are great differences between the $16 \mathrm{~S}$ sequence phylogeny and the classification based on morphological, physiological and biochemical studies. For these reasons, the search for an alternative tool, such as a gene encoding a protein, is intensifying (Birtles \& Raoult, 1996; Christensen \& Olsen, 1998; Morse et al., 1996; Roux et al., 1997; Springer et al., 1995).

\section{Comparison of 16S rRNA and mle phylogenetic analysis}

Although the MLE is not described as existing outside LAB, not all LAB contain it. Comparisons of similarity values showed that this gene is less conserved than 16S rRNA gene in LAB. The dendrograms inferred from $16 \mathrm{~S}$ rRNA and mle sequences had different profiles. $P$. acidilactici and $P$. parvulus were 
Malate Binding site

$\mathrm{BOx}$

S. pombe

S. cerevisiae

H. sapiens (cytosol)

S. scrofa

M. musculus

A. platyrhynchos

C. Livia

H. sapiens (mito)

A. suum

M. crystallinum

F. trinervia

P. trichocarpa

V. vinifera

P. vulgaris

z. mays

o. saliva

T. vaginalis

G. intestinalis

S. tuberosum

A. hypochondriacus

N. frontalis

E. Coli

Lb. rhamnosus

Lb. plantarum

Lb. brevis

t. mesenteroides

Lb. salivarius

. oeni

Lc. lactis

$P$, parvulus

P. acidilactic

Lb. hilgardi

Lb. fructivorans

Identical (*) and

similar (.) residue

- and . mle spactica

+ and . me specifics

s. pombe

S. cerevisiae

H. sapiens (cytosol)

s. scrofa

M. musculus

A. platyrhynchos

C. Livia

H. sapiens (mito)

A. suun

M. Crystallinum

F. trinervia

P. trichocarpa

V. vinifera

P. vulgaris

z. mays

o. saliva

T. vaginalis

G. intestinalis

s. tuberosum

A. hypochondriacus

N. frontalis

E. coli

Lb. rhamrosus

Lb. plantarum

L.b. brevis

L. mesenteroides

Lb. salivarius

. ceni

LC. lactis

P. parvilus

P. acidilactici

Lb. hilgarai

tb. Eructivorans

Identical (*) and

similar (.) resicues

Malate Binding site

97MPIVYTPTVGLACQQYSLVPRKP-RGLFITIHDR--GHIASVLNAWPE-DVIKAIVVTDGERILGLG--DLGCNGMGIPVGKLALYTACGGMNPQECLPVILDVGTENEELL-KDPL 207 83MP IVYTPTVGLACOOYSLAFRXP-RGLFISIHDR--GHVASVLNAWPE-DVIKAVVVTDGFRILGLG--DLGCNGMGIPVGKLALYTACGGVNPQECLPVILDVGTENEELL-KDPL 193 97 MP IVYTPTVGLACQRYSLAFRKP-RGLFISIHDK--GHIASVLNAWPE-DVVKAIVVTDGERILGLG--DLGCNGMGIPVGKLALYTACGGVNPQQCLPITLDVGTENEELL-KDPL 207 86MPIVYTPTVGLACQQYGLAPRRP-RGLFITIHDR--GHIATMLKSWPE-SVIKAIVVTDGERILGLG--DLGCYGMGIPVGKLALYTACGGVKPHECLPVMLDVGTDNEALL-KDPL196 86MP IVYTPTVGLACQHYGLAPRRP-RGLF ITIHDR--GHIATMLQSWPE-SVIKAIVVTDGERILGLG--DLGCYGMGIPVGKLALYTACGGVKPHQCLPVMLDVGTDNETLL-KDPL196 105MPIVYT PTVGLACSOYGHI PRRP-KGLFISISDR- -GHVRSIVDNWPE-NHVKAVVVTDGERI LGLG- - DLGVYGMGIPVGKLCLYTACAGIRPDRCLPVCIDVGTDN IALL-KDPF 215 133 MPIVYTPTVGIACONFGYIYRKF-KGLYITINDNSVSK IYOILSNWHE-EDVRAIVVTDOGRILGTO-DLGAYGIGIPVGKLALYVALGGVCPKWCLPVLLDVGTNNMDLL-NDPF 245 128LPLV PTGFGCKYGSIPRRP-OGLFISLKDK --GRTLELLRNWPE-KKIOVIVVTDGERI LGLG--DLGCOGMGIPVGKLSLYSALGGVCPSACLPITLDVGTNNOKLL-DDEF 238 190LPIVYTPTVGBACQKYGSIPENS-QGLF ISLKDK- -GRILEILKNWPH-KKIQVIVVTDGERILGLG-DLGCQGMGIPVGKLALYTALGGVRPSACLPITIDVGTNNEKLLNDDEF 300 134 LPVVYT PTVGEACQKYGS I FKRP-QGLY I SLKEK--GKVLDVLKNWPQ-KSIQVIVVTDGERI LGLG--DLGCQG IGIPVGKLSLYTALGGVRP SACLPVTIDVGTNNEQLL-KDEF 244 134LPVVYTPTVGEACOKYGSIFRRP-OGLYISLKEK--GKILEVLKNWPE-RRIOVIVVTDGERILGLO--DLGCOGMGIPVGKLSLYTALGGVRPSACLPITIDVGTNNEKLL-ANEF244 132LPVVYTPTVGFACOKYGSI FRRP -OGLY ISLKEK--GKILEVLKNWPE-KSIQVIVVTDGERI LGLG--DLGCQGMGI PVGKLSLYTALGGVRPSSCLPVTIDVGTNNEKLL-NDEF242 179 LPFVYTPTVGEACOKYGSI FGRP-QGLYVSLKDK--GKVLEVLRNWPH-RNIQVICVTDGERILGLG--DLGCQGMGI IVGKLALYTALGGVDFSVCLPITIDVGTNNEFLL-NDEF 289

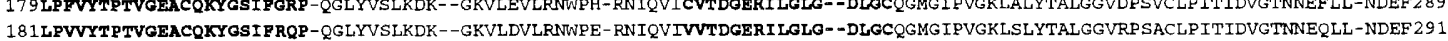
107 MPVLYTPTVGEACQKATTHRQSY-RGIY ITPEDS--GKIKDILRNYPR-QDIRCIVVTDAGRI LGLG--DLGASGLGIPVGKLMLYTLIGQVNPDQTLPVQLDMGTDRKEIL-ADPL217 87 LPIVYTPTVOTACSNYSLLWQGYPRGFYLNRTHL--GKVRQIFDQWP- -YSPRIIVATDGTRILGLO--DLGTGGHQICVGKLTLYSLGGGFAPEHTLPISFDFGCNTDK IR-EDPH197 124API IYTPTVGLVCONY SGLPRRP-RGMYFSAKDK- - GEMMSMIFNWPS-TQVDM IVLTDGSRI LGLG--DLGVQG IG IP IGKLDMYVAAAGINPQRVLPVMLDVGTTNQKLL-EDFL234 138 APIVSTPTVGLVCOKF SGLYRRP-RGMYFSSDDR--GEMMSMVYNWPA-EQVDMIVVTDGSRILGLG--DLGVHG IGVAIGKLDLYVAAAGINPORVLPVMIDVGTNNEDLL-KNPL248 129API I YTPVVGEACQKPHKIFTQT-RGMYFSTADR--GQMSAVAANWPY-DDVDVIVVTDGSRI LGLG--DLGAGGMQIP IGKLTLYVCGGG INPRNVLPIVLDVGTNNKELLL-NDPL239 108 MPVI YTPTVGAACERFSE I YRRS-RGVF ISYQNR-- HNMDDILQNVPN-HNIKVIVVTDGERI LGLG--DQGI GGMGIPIGKLSLYTACGGISPAYTLPVVLDVGTNNQQLL-NDPL2 18 1-------VVADSI EQYNELPLDPQNAAFVSVDA-- PEDIEATLKNAADGRDIRLVVVTDAEGILGMG--DWGVNGVDIAIGKLMVYTAAAGIDPSQVLPVSIDAGTNNQKLL-DDPL105 1 NPVYYDPVADSI EOYNEIFLDPQNAAFVSVDA- - PEDIEATLKNARGRRDIRLVVVTDAEGI LGMG- - DWGVNGVDIAIGKLMVYTAAAGIDPSQVLPVSIDAGTNNQKLL-DDPL112 1 NPVYYDPTVADS I EOYSHLFTDPONAAFI SVDA-- PEDIEATLKNAAGDRDIRLVVVTDAEG I LGMG-- DWGVNGVDIAVGKLMVYTAAAGMIQHKSCOLALMAGTNNQTLL-NDRY112 1 - PVVYDPIVAES I EQYNEI YTNP QNAAFLSIDH-- PENIESSLKSVADGRDIELVVVTDAEGILGMG--DWGVNGVDIAVGKLMVYTAAAGIDPATVLPVSIDAGMNNKILL-ENPL 11 1------ LLNQSKDT I IYLCVLKKQHLFQS-DK-- PESIETTLKRAADGRDIRL IVVTDAEGI LGIG--DWGVDGVDIAIGKLMVYTAAAG INPAQVLPVSIDAGTNNKELL - NDPL104 1-PIVYDPTI IADTI IENYSELFVEPQGAAFLDINH- - PENIQKTLKNAANGRDIKLLVVSDAEGI LGIG- - DWGVQGVDIAVGKLMVYTVAAGIDPSTVLAVVIDAGTNNEKLL-KDPM111 1NPVVYDPTIADT IENYSHLFVDPQYAAYLDINH- -PENITETLKNAAGDREIRLIVVTDAEGILGIG- -DWGTQGVDISVGKLMIYTAAAGIDPASVLPVVIDAGTNRRELL-EDHL11.2

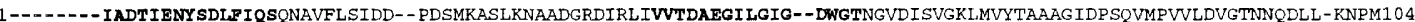
1--.---TIADTIENYSELYVQS QNATFLSIDD- - PDNMETALKNAADGRDIRL IVVTDAEGILGIG- -DWGTNGVDISVGKLMVYTAAAGIDPSQVLPVVLDVGTNNEKLL-KDPM105 1-PVVYDPTIADTI ENYSHLPLDPQNAAFLSIDD-- QDDIEASL KNASAGCDIKLIVVTDGEGILGIG--DWGVQGVDISVGKLMVYTAAAGVDPKSVLPVVLDVGTNRKELL-ADDL 111 1NSVVYDPTIADS IENYSRLYVNPQNAAFLSIDHDDPETIRESLKNTAAGRNIKLIVVTDGEGILGIG--DWGTQGIDIPVGKLMVYSAAAGIDPSEVLPVVMDVGTTNKSLL-DNPL114

212YMGLRKDRVRGEQYDSLDNVIKAIREVFPE-AFIHFEDFGLANAKRILDHYRPDIACPNDDIQGTOA

$* * \ldots * \ldots . .$.

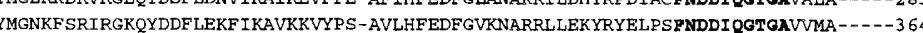

38Y IGLRQRRVRGSEYDDFLDEFMEAVSSKYGMNCLIOFEDFANVNAFRLLNKYRNOYCTPNDDIOCTASVAVA - . - - 280 194 Y IGLRQRRVRGPEYDDFLDEFMEAVSSKYGMNCLIQFEDF ANINAFRLLKKYQNQYCTPNDDIQGTASVAVAG- - - 267 $208 Y$ IGLRHRRVRGPEYDAFLDEFMEAASSKYGMNCLIQFEDF ANRNAFRL LNKYRNKYCTPNDDIQGTASVAVA-- - - 280 197 Y IGLRHKRIRGQAYDDLLDEFMEAVTSRYGMNCLIQFEDF ANANAFRL LHKYRNKYCTFNDDIQGTASVAVAG- - - 270 197 Y IGLRHKRIRGQAYDDL LDEFMEAVTSRYGMNCL I QFEDFANANAFRL LHKYRNKYCTFNDDIOGTASVAVAG - - - 270 216YMGLYQKRDRTQOYDDL IDEFMKAITDRYGRNTL IOFEDFGNHNAFRFLRKYREKYCTFNDDIOGTAAVA-- - - - - 286 246YIGLRHKRVRGKDYDTLLDNFMKACTKKYGQKTLIQFEDFANPNAFRL LDKYQDKYTMFNDDIQGTASVIVAG - - - 319 239Y IGLKQKRATGEEYAEFVQEFMSAVKQNYGEKILVQFEDFANHNAFELLEKYRT'THLVFNDDIQGTASVVLA- - - - 311 301 Y IGLKQKRAAGQEYAELMNEFMSAVKQNYGENLLIQFEDFANHNAFDLLEKYRTTHLVFNDDIQOTASVVLGG-- - 374 245Y IGLRQRRATGQEYSELLHEFMTAVKQNYGEKVLIQFEDFANHNAFDLLAKYGTTHLVFNDDIQGTAAVVLAG- - - 318 245Y IGLKQRRATGKEYSEFLQEFMSPVKQNYGEKVL IOFEDFANHNAFDL LAKYGTTHLAPNDDIQGTASVVLAG - -- -318 243Y IGLRQRRATGQEYATFLDEFMRAVKONYGEKVLVOFEDFANHNAFDL LEKYSSSHLVPNDDIOGTASVVLAG- - - 316 290YIGLRQKRATGEEYOELIEEFMSAVKQFYGEKVLIQFEDFANHNAFDLLEKYSKSHLVFNDDI QGTASVVLAG- - - - -363 292 Y IGLRQRRATGKEYHELMEEFMSAVKQ IYGEKVLIQFEDFANHNAFDLLAKYSKSHLVFNDDIQGTASVVLAG-- - - 365 218YHGWRHPR IRGPEH'TKFVAEFVDAVKEVFGETCLVQPEDFEMETAFTLLDHFRWRCNCENDDIEGTAAVA- - - - - - 288 198YLGI PEKRNKDDTYYGI IKETIEAVHSKWFD-CIFQFEDF SNDTAFTLLKKHRDAGPVFNDDIQGTGCIAAATIAAG275 235YLGLRQPRLEGEEYLSIVDEFVEAVHARWPK-AVVOFEDFOAKWAFETLDRYRKKFCMPNDDIOGTAGVALA - - - - 306 249YLGLQKKRLDGEEYLAVMDEFMEAVFTRWPN-VIVQFEDIQNKWALTL LQRYRHKYRTPNVDVQGTSGVAIAG- - - 321 240 YLGMQHPRLQGEEFHAFVDEWV SAITDRFPK-AVIQFEDFMMPNA.LDLLLKYKDQ ICM FNDDIQSTGAITLA- - - - 31 219YMGWRNPRITDDEYYEFVDEF IQAVKQRWPD-VLLQFEDFAQKNAMP LLNRYRNEICSFNDDIQGTAAVIVG - - - - 290 106YLGNRHKRVSGEQYYDVIDKFVAAEQQLFPD-SLLHFEDEGRDNAQVILDKYKDQIAT113YLGNRHKRVSGEQYYDVIDKFVAAEQQLFPD-SLLHFEDFGRDNAQVILDKYKDQIATFNDDIOGT . . . . . . . - - 177 113 YLGNHHERVYGDKYHAVIDQFVAAEQKLFPE-SLLHWEDFGRSNAQVILDKYKDKIATPNDDIQGT- - . $\ldots \ldots$ 112 YLGNKHERI AGEKYLEF IDEFVTAEQKLFPA-SLLHWEDF GRSNAQVI LDKYKDS I ATPNDDI QGTGI … 105YLGNKHKRVYGEKYNEL I DKFVAAVQKLFPE-SMLHFEDFGRSNADVILNKYKDKILT - . 112YLGNKFNRVRGDKYYDFIDKFVNHAESLF PN-LYLHWEDFGRSNASNILNSYKDKI ATFNDDIQGTGI 113 YLGNHQERIYGDQYYSFVDQFVETAES IFPK-LYLHWEDFGRSNAAT I LNYYKTK IPTFNDDIOGTGIVV- $\ldots$ 105 YLGNRHERITGDRYYKFVDQFVNTAEDLFPK - LYLRFEDFGRDNAANI LNKYKDQ ITT106 Y LGNRHERIKGDRYFEFVDQFVQTAENLFPN-MYLHFEDFGA

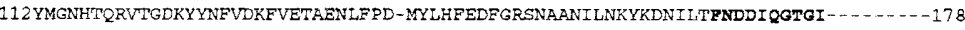
115YLGNHQDRDYGQKYYDFVDKFVKEAEDLFPN-LYLHFEDFGRRNASNILDKYKDDYLVFNDDIQGT- .

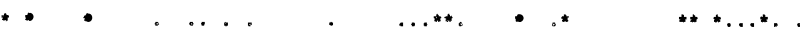

- and . ml specifics

* and . me specifics$$
* \ldots * \ldots * \quad \cdots * \ldots * * * * * * * * * *
$$

Fig. 4. Alignment of partial amino acid sequences of different malic and malolactic enzymes. 
indicative of a $\mathrm{NADP}^{+}$-dependent malic enzyme. All the MLEs studied in this report or previously purified (Caspritz \& Radler, 1983; Lonvaud, 1975; LonvaudFunel \& Strasser de Saad, 1982; Naouri et al., 1990; Spettoli et al., 1984) are $\mathrm{NAD}^{+}$-dependent. Indeed, they do not have cysteine but threonine or valine at this consensus site. The importance of a cysteine in malate binding has been demonstrated by $\mathrm{SH}$ reagent inhibition studies in several malic enzymes (Chang et al., 1993; Gavva et al., 1991). This residue is replaced by isoleucine in MLEs (lysine for Lactobacillus salivarius), and there are very few cysteine residues in MLE sequences. The first hypothesis was that this cysteine is essential in understanding the different functions of these two similar enzymes. However, the malic enzymes of Schizosaccharomyces pombe and Saccharomyces cerevisiae also have isoleucine, like the MLEs. So, if an SH group intervenes since pyruvate is released by malic enzymes, another cysteine is involved in yeast malic enzymes. Amino acid sequence analysis of the two enzymes shows some other interesting residues that are specific either to malic enzymes or to MLEs. For example, in the malate-binding site a conserved aspartate in MLEs is replaced by a threonine in malic enzymes.

Therefore, it appears that malic and malolactic enzymes are close proteins. No crystallographic threedimensional structure is yet available for these two enzymes. Therefore, site-directed mutagenesis studies are needed to find why the MLE, unlike malic enzyme, transforms malate to lactate without release of intermediate products, such as pyruvate or $\mathrm{NADH}$.

\section{REFERENCES}

Ansanay, V., Dequin, S., Blondin, B. \& Barre, P. (1993). Cloning, sequence and expression of the gene encoding the malolactic enzyme from Lactococcus lactis. FEBS Lett 332, 74-80.

Bagchi, S., Wise, L. S., Brown, M. L., Sul, H. S., Bregman, D. B. \& Rubin, C. S. (1986). Regulation and structure of murine malic enzyme mRNA. Ann N Y Acad Sci 478, 77-92.

Bairoch, A. (1991). PROSITE: a dictionary of sites and patterns in proteins. Nucleic Acids Res 19 (suppl.), 2241-2245.

Batterman, G. \& Radler, F. (1990). A comparative study of malolactic enzyme and malic enzyme of different lactic acid bacteria. Can J Microbiol 37, 211-217.

Birnboim, H. C. \& Doly, J. (1979). A rapid alkaline extraction procedure for screening recombinant plasmid DNA. Nucleic Acids Res 7, 1513-1523.

Birtles, R. J. \& Raoult, D. (1996). Comparison of partial citrate sythase gene $(\mathrm{glt} \mathrm{A})$ sequences for phylogenetic analysis of Bartonella species. Int J Syst Bacteriol 46, 891-897.

Boles, E., de Jong-Gubbels, P. \& Pronk, J. T. (1998). Identification and characterization of MAE1, the Saccharomyces cerevisiae structural gene encoding mitochondrial malic enzyme. $J$ Bacteriol 180, 2875-2882.

Borsch, D. \& Westhoff, P. (1990). Primary structure of NADPdependent malic enzyme in the dicotyledonous $\mathrm{C} 4$ plant Flaveria trinervia. FEBS Lett 273, 111-115.

Buchanan, R. E. \& Gibbons, N. E. (1986). Bergey's Manual of
Determinative Bacteriology, 9th edn. Baltimore: Williams \& Wilkins.

Bullock, W. O., Fernandez, J. M. \& Short, J. M. (1987). XL1-Blue: a high efficiency plasmid transforming RecA Escherichia coli strain with $\beta$-galactosidase selection. BioTechniques 5, 376-379.

Caspritz, G. \& Radler, F. (1983). Malolactic enzyme of Lactobacillus plantarum. Purification, properties, and distribution among bacteria. $J$ Biol Chem 258, 4907-4910.

Chang, G. G., Satterlee, J. \& Hsu, R. Y. (1993). Essential sulfhydryl group of malic enzyme from Escherichia coli. $J$ Protein Chem 12, 7-10.

Chou, W. Y., Huang, S. M., Liu, Y. H. \& Chang, G. G. (1994). Cloning and expression of pigeon liver cytosolic $\mathrm{NADP}^{+}$dependent malic enzyme cDNA and some of its abortive mutants. Arch Biochem Biophys 310, 158-166.

Christensen, H. \& Olsen, J. E. (1998). Phylogenetic relationships of Salmonella based on DNA sequence comparison of atpD encoding the beta subunit of ATP synthase. FEMS Microbiol Lett 161, 89-96.

Collins, M. D., Farrow, J. A. E., Phillips, B. A., Ferusu, S. \& Jones, D. (1987). Classification of Lactobacillus divergens, Lactobacillus piscicola and some catalase-negative, asporogenous, rodshaped bacteria from poultry in a new genus, Carnobacterium. Int J Syst Bacteriol 37, 310-316.

Collins, M. D., Williams, A. M. \& Wallbanks, S. (1990). The phylogeny of Aerococcus and Pediococcus as determined by $16 \mathrm{~S}$ rRNA sequence analysis: description of Tetragenococcus gen. nov. FEMS Microbiol Lett 58, 255-262.

Collins, M. D., Rodrigues, U., Ash, C., Aguirre, M., Farrow, J. A. E., Martínez-Murcia, A., Phillips, B. A., Williams, A. M. \& Wallbanks, S. (1991). Phylogenetic analysis of the genus Lactobacillus and related lactic acid bacteria as determined by reverse transcriptase sequencing of $16 \mathrm{~S}$ rRNA. FEMS Microbiol Lett 77, 5-12.

Collins, M. D., Samelis, J., Metaxopoulos, J. \& Wallbanks, S. (1993). Taxonomic studies on some leuconostoc-like organisms from fermented sausages: description of a new genus Weissella for the Leuconostoc paramesenteroides group of species. $J$ Appl Bacteriol 75, 595-603.

Cushman, J. C. (1992). Characterization and expression of a NADP-malic enzyme cDNA induced by salt stress from the facultative crassulacean acid metabolism plant, Mesembryanthemum crystallinum. Eur J Biochem 208, 259-266.

Denayrolles, M., Aigle, M. \& Lonvaud-Funel, A. (1994). Cloning and sequence analysis of the gene encoding Lactococcus lactis malolactic enzyme: relationships with malic enzymes. FEMS Microbiol Lett 116, 79-86.

De Roissart, H. \& Luquet, F. M. (editors) (1994). Bactèries Lactiques. Aspects Fondamentaux et Technologiques, vol. 1, pp. 133-137. Uriage: Lorica.

Dicks, L. M. T., Dellaglio, F. \& Collins, M. D. (1995). Proposal to reclassify Leuconostoc oenos as Oenococcus oeni (corrig.) gen. nov., comb. nov. Int J Syst Bacteriol 45, 395-397.

Dicks, L. M. T., Du Plessis, E. M., Dellaglio, F. \& Lauer, E. (1996). Reclassification of Lactobacillus casei subsp. casei ATCC 393 and Lactobacillus rhamnosus ATCC 15820 as Lactobacillus zeae nom. rev., designation of ATCC 334 as the neotype of $L$. casei subsp. casei, and rejection of the name Lactobacillus paracasei. Int $J$ Syst Bacteriol 46, 337-340.

Felsenstein, J. (1989). PHYLIP: phylogeny inference package. Cladistics 5, 164-166.

Fox, G. E., Wisotzkey, J. D. \& Jurtshuk, P. (1992). How close is 
close: 16S rRNA sequence identity may not be sufficient to guarantee species identity. Int J Syst Bacteriol 42, 166-170.

Franke, K. E. \& Adams, D. O. (1995). Cloning of a full-length cDNA for malic enzyme (EC 1.1.1.40) from grape berries. Plant Physiol 107, 1009-1010.

Fushimi, T., Umeda, M., Shimazaki, T., Kato, A., Toriyama, K. \& Uchimiya, H. (1994). Nucleotide sequence of a rice cDNA similar to a maize NADP-dependent malic enzyme. Plant Mol Biol 24, 965-967.

Gasson, M. J. \& Davies, F. L. (1980). Conjugal transfer of drug resistance plasmid $\mathrm{pAM} \beta 1$ in lactic streptococci. FEMS Microbiol Lett 7, 51-53.

Gavva, S. R., Harris, B. G., Weiss, P. M. \& Cook, P. F. (1991). Modification of a thiol at the active site of the Ascaris suum NAD-malic enzyme results in changes in the rate-determining steps for oxidative decarboxylation of L-malate. Biochemistry 30, 5764-5769.

Gonzalez-Manchon, C., Ferrer, M., Ayuso, M. S. \& Parrilla, R. (1995). Cloning, sequencing and functional expression of a cDNA encoding a NADP-dependent malic enzyme from human liver. Gene 159, 255-260.

Harty, D. W., Oakey, H. J., Patrikakis, M., Hume, E. B. \& Knox, K. W. (1994). Pathogenic potential of lactobacilli. Int J Food Microbiol 24, 179-189.

Hrdy, I. \& Müller, M. (1995). Primary structure of the hydrogenosomal malic enzyme of Trichomonas vaginalis and its relationship to homologous enzymes. $J$ Eukaryot Microbiol 42, 593-603.

Hsu, R. Y., Glynias, M. J., Satterlee, J. \& 7 other authors (1992). Duck liver 'malic' enzyme. Expression in Escherichia coli and characterization of the wild-type enzyme and site-directed mutants. Biochem $J$ 284, 869-876.

Johnson, J. L. (1984). Bacterial classification. III. Nucleic acids in bacterial classification. In Bergey's Manual of Systematic Bacteriology, vol. 1, pp. 8-11. Edited by N. R. Krieg \& J. G. Holt. Baltimore: Williams \& Wilkins.

Kawai, S., Suzuki, H., Yamamoto, K., Inui, M., Yukawa, H. \& Kumagai, H. (1996). Purification and characterization of a malic enzyme from the ruminal bacterium Streptococcus bovis ATCC 15352 and cloning and sequencing of its gene. Appl Environ Microbiol 62, 2692-2700.

Kulkarni, L. P., Cook, P. F. \& Harris, B. G. (1993). Cloning and nucleotide sequence of a full-length cDNA encoding Ascaris suum malic enzyme. Arch Biochem Biophys 300, 231-237.

Labarre, C., Guzzo, J., Cavin, J. F. \& Divies, C. (1996). Cloning and characterization of the genes encoding the malolactic enzyme and the malate permease of Leuconostoc oenos. Appl Environ Microbiol 62, 1274-1282.

Lane, D. L., Pace, B., Olsen, G. J., Stahl, D. A., Sogin, M. L. \& Pace, N. R. (1985). Rapid determination of $16 \mathrm{~S}$ ribosomal RNA sequences for phylogenetic analysis. Proc Natl Acad Sci USA 82, 6955-6959.

Loeber, G., Infante, A. A., Maurer-Fogy, I., Krystek, E. \& Dworkin, M. B. (1991). Human $\mathrm{NAD}^{+}$-dependent mitochondrial malic enzyme: cDNA cloning, primary structure, and expression in Escherichia coli. J Biol Chem 266, 3016-3021.

London, J. \& Meyer, E. Y. (1969). Malate utilization by a group D Streptococcus, physiological properties and purification of a inductible malic enzyme. J Bacteriol 98, 705-711.

Long, J. J., Wang, J. L. \& Berry, J. O. (1994). Cloning and analysis of the C4 photosynthetic NAD-dependent malic enzyme of Amaranth mitochondria. J Biol Chem 269, 2827-2833.
Lonvaud, M. (1975). Recherches sur l'enzyme des bactéries lactiques $d u$ vin assurant la transformation du malate en lactate. Thèse de 3ème cycle, Université de Bordeaux II.

Lonvaud, M. \& Ribereau-Gayon, P. (1973). Utilisation d'une électrode $\mathrm{CO}_{2}$ pour la détermination de l'activité de 'l'enzyme malique' des bactéries lactiques du vin. $C R$ Acad Sci D 276, 2329-2331.

Lonvaud-Funel, A. \& Strasser de Saad, A. M. (1982). Purification and properties of a malolactic enzyme from a strain of Leuconostoc mesenteroides isolated from grapes. Appl Environ Microbiol 43, 357-361.

Lonvaud-Funel, A., Fremaux, C., Biteau, N. \& Joyeux, A. (1991). Speciation of lactic acid bacteria from wine by DNA hybridization with DNA probes. Food Microbiol 8, 215-222.

Mahayan, S. K., Chu, C. C., Willis, D. K., Templin, A. \& Clark, A. J. (1990). Physical analysis of spontaneous and mutagen-induced mutants of Escherichia coli $\mathrm{K}-12$ expressing DNA exonuclease VIII activity. Genetics 125, 261-273.

Martínez-Murcia, A. J. \& Collins, M. D. (1990). A phylogenetic analysis of the genus Leuconostoc based on reverse transcriptase sequencing of $16 \mathrm{~S}$ rRNA. FEMS Microbiol Lett 58, 73-83.

Miller, J. H. (1972). Experiments in Molecular Genetics. Cold Spring Harbor, NY: Cold Spring Harbor Laboratory.

Morse, R., Collins, M. D., O’Hanlon, K., Wallbanks, S. \& Richardson, P. T. (1996). Analysis of the $\beta$ ' subunit of DNAdependent RNA polymerase does not support the hypothesis inferred from 16S rRNA analysis that Oenococcus oeni (formerly Leuconostoc oenos) is a tachytelic (fast-evolving) bacterium. Int J Syst Bacteriol 46, 1004-1009.

Naouri, P., Chagnaud, P., Arnaud, A. \& Galzy, P. (1990). Purification and properties of a malolactic enzyme from Leuconostoc anos ATCC 23278. J Basic Microbiol 30, 577-585.

Oakey, H. J., Harty. D. W. \& Knox, K. W. (1995). Enzyme production by lactobacilli and the potential link with infective endocartis. J Appl Bacteriol 78, 142-148.

Rothermel, B. A. \& Nelson, T. (1989). Primary structure of the maize NADP-dependent malic enzyme. $J$ Biol Chem 264, 19587-19592.

Roux, V., Rydkina, E., Eremeeva, M. \& Raoult, D. (1997). Citrate synthase gene comparison, a new tool for phylogenetic analysis, and its application for the Rickettsiae. Int J Syst Bacteriol 47, 252-261.

Salminen, S. \& von Wright, A. (editors) (1998). Lactic Acid Bacteria. Microbiology \& Functional Aspects, 2nd edn, pp. 1-22. New York: Marcel Dekker.

Sanchez, L. B., Hashimoto, T. \& Müller, M. (1996). Sequence of a malic enzyme gene of Giardia lamblia. Mol Biochem Parasitol 82, 145-151.

Saxelin, M., Chuang, N. H., Chassy, B., Rautelin, H., Makela, P. H., Salminen, S. \& Gorbach, S. L. (1996). Lactobacilli and bacteremia in southern Finland, 1989-1992. Clin Infect Dis 22, 564-566.

Smith, P. K., Khron, R. I., Hermanson, J. T. \& 7 other authors (1985). Measurement of protein using bicinchoninic acid. Anal Biochem 150, 76-85.

Sohier, D., Coulon, J. \& Lonvaud-Funel, A. (1999). Molecular identification of Lactobacillus hilgardii and genetic relationships with Lactobacillus brevis. Int J Syst Bacteriol 49, 1075-1081.

Spettoli, P., Nuti, M. P. \& Zamora, A. (1984). Properties of malolactic activity purified from Leuconostoc anos ML34 by affinity chromatography. Appl Environ Microbiol 48, 900-903.

Springer, E., Sachs, M. S., Woese, C. R. \& Boone, D. R. (1995). 
Partial gene sequences for the A subunit of methyl-coenzyme M reductase $(\mathrm{mcr}$ I) as a phylogenetic tool for the family Methanosarcinaceae. Int J Syst Bacteriol 45, 554-559.

Stiles, M. E. \& Holzapfel, W. H. (1997). Lactic acid bacteria of foods and their current taxonomy. Int J Food Microbiol 36, $1-29$.

Thompson, J. D., Higgins, D. G. \& Gibson, T. J. (1994). CLUSTAL $\mathrm{w}$ : improving the sensitivity of progressive multiple sequence alignment through sequence weighting, position-specific gap penalties and weight matrix choice. Nucleic Acids Res 22, 4673-4680.

Vandamme, P., Pot, B., Gillis, M., de Vos, P., Kersters, K. \& Swings, J. (1996). Polyphasic taxonomy, a consensus approach to bacterial systematics. Microbiol Rev 60, 407-438.

Van der Glezen, M., Rechinger, K. B., Svendsen, I., Durand, R., Hirt, R. P., Fevre, M., Embley, T. M. \& Prins, R. A. (1997). A mitochondrial-like targeting signal on the hydrogenosomal malic enzyme from the anaerobic fungus Neocallimastix frontalis: support for the hypothesis that hydrogenosomes are modified mitochondria. Mol Microbiol 23, 11-21.

Van Doorsselaered, J., Villaroel, N., Montagu, V. \& Inze, D. (1991). Nucleotide sequence of a cDNA encoding enzyme from poplar. Plant Physiol 96, 1385-1386.

Viljoen, M., Subden, R. E., Krizus, A. \& van Vuuren, H. J. J. (1994). Molecular analysis of the malic enzyme gene (mae2) of Schizosaccharomyces pombe. Yeast 10, 613-624.

Wallbanks, S., Martínez-Murcia, A. J., Fryer, J. L., Phillips, B. A. \& Collins, M. D. (1990). 16S rRNA sequence determination for members of the genus Carnobacterium and related lactic acid bacteria and description of Vagococcus salmoninarum sp. nov. Int J Syst Bacteriol 40, 224-230.

Walter, M. H., Grima-Pettenati, J., Grand, C., Boudet, A. M. \&
Lamb, C. J. (1990). Extensive sequence similarity of the bean CAD4 (cinnamoyl-alcohol dehydrogenase) to a maize malic enzyme. Plant Mol Biol 15, 525-526.

Wei, C. H., Chou, W. Y., Huang, S. M., Lin, C. C. \& Chang, G. G. (1994). Affinity cleavage at the putative metal-binding site of pigeon liver malic enzyme by the $\mathrm{Fe}^{2+}$-ascorbate system. Biochemistry 33, 7931-7936.

Wei, C. H., Chou, W. Y. \& Chang, G. G. (1995). Identification of $\mathrm{Asp}^{258}$ as the metal coordinate of pigeon liver malic enzyme by site-specific mutagenesis. Biochemistry 34, 7949-7954.

Wierenga, R. K., De Maeyer, M. C. H. \& Hol, W. G. J. (1985). Interaction of pyrophosphate moieties with $\alpha$-helixes in dinucleotide binding proteins. Biochemistry 24, 1346-1357.

Winning, B. M., Bourguignon, J. \& Leaver, C. J. (1994). Plant mitochondrial $\mathrm{NAD}^{+}$-dependent malic enzyme. cDNA cloning, deduced primary structure of the $59-$ and $62-\mathrm{kDa}$ subunits, import, gene complexity and expression analysis. $J$ Biol Chem 269, 4780-4786.

Woese, C. R. (1987). Bacterial evolution. Microbiol Rev 51, 221-271.

Yang, D. \& Woese, C. R. (1989). Phylogenetic structure of the 'Leuconostocs': an interesting case of a rapidly evolving organism. Syst Appl Microbiol 12, 145-149.

Zapparoli, G., Torriani, S., Pesente, P. \& Dellaglio, F. (1998). Design and evaluation of malolactic enzyme gene targeted primers for rapid identification and detection of Oenococcus oeni in wine. Lett Appl Microbiol 27, 243-246.

Zavaleta, A. I., Martínez-Murcia, A. J. \& Rodriguez-Valera, F. (1997). Intraspecific genetic diversity of Oenococcus oeni as derived from DNA fingerprinting and sequence analysis. Appl Environ Microbiol 63, 1261-1267. 